\title{
Antitumour activity of TH1579, a novel MTH1 inhibitor, against castration-resistant prostate cancer
}

\author{
MINGQIU HU, JING NING, LIKAI MAO, YUANYUAN YU and YU WU \\ Department of Urology, The Second Affiliated Hospital of Bengbu Medical College, Bengbu, Anhui 233040, P.R. China
}

Received June 13, 2020; Accepted November 2, 2020

DOI: $10.3892 / \mathrm{ol} .2020 .12324$

\begin{abstract}
Castration-resistant prostate cancer (CRPC) treatment still remains difficult. The aim of the present study was to determine the antitumour efficacy of the MutT homolog 1 (MTH1) inhibitor, TH1579, against castration-resistant prostate cancer. PC-3 and DU-145 prostate cancer cells were treated with different concentrations of TH1579. C4-2 cells with or without androgen receptor (AR) were also treated with TH1579 to assess AR function. Cell survival, 8-oxo-dG levels and DNA damage were measured using cell viability assays, western blotting, immunofluorescence analysis and flow cytometry. TH1579 inhibited CRPC cell proliferation in a dose-dependent manner. The viabilities of PC-3 and DU-145 cells treated with $1 \mu \mathrm{M}$ of TH1579 were 28.6 and $24.1 \%$, respectively. The viabilities of $\mathrm{C} 4-2$ cells with and without AR treated with $1 \mu \mathrm{M}$ TH1579 were 10.6 and $19.0 \%$, respectively. Moreover, TH1579 treatment increased 8-oxo-dG levels, as well as the number of 53BP1 and $\gamma \mathrm{H} 2 \mathrm{~A} . \mathrm{X}$ foci, resulting in increased DNA double-strand breakage and apoptosis in PC-3 and DU-145 cells. The findings of the present study demonstrated that TH1579 exerted strong antitumour effects on CRPC cells, and may therefore be used as a potential therapeutic agent for the clinical treatment of CRPC.
\end{abstract}

\section{Introduction}

Prostate cancer is the leading type of non-skin cancer and the fifth leading cause of cancer-associated death among men in the United States, as well as a major public health burden worldwide (1). Most prostate cancers are initially sensitive to androgen deprivation treatment; however, they

Correspondence to: Dr Mingqiu Hu, Department of Urology, The Second Affiliated Hospital of Bengbu Medical College, 220 Hongye Road, Bengbu, Anhui 233040, P.R. China

E-mail: humingqiu@me.com

Abbreviations: MTH1, MutT homolog 1; CRPC, castration-resistant prostate cancer; dNTP, deoxynucleotide triphosphate; DSB, double-strand break; AR, androgen receptor

Key words: MTH1, CRPC, 8-oxo-dG, antitumour progress to a castration-resistant state after a median interval of 18-24 months $(2,3)$. While cytotoxic compounds such as docetaxel are effective against castration-resistant prostate cancer (CRPC), they may produce dose-limiting toxicity in normal tissues (2). Currently, there is no effective treatment that substantially improves the overall survival of patients with CRPC (2).

Several studies have demonstrated a positive association between cancer and the imbalance of redox homeostasis and/or increased levels of reactive oxygen species $(4,5)$, which oxidise nucleobases in the free deoxynucleotide triphosphate (dNTP) pool. High levels of 8-oxo-dG, a major product of reactive oxygen species-induced cellular damage (5), can promote apoptosis and inhibit cellular proliferation (5). Accordingly, the incorporation of oxidised 8-oxo-dG into DNA can suppress tumour growth (6). Human MutT homolog 1 (MTH1, also known as Nudix hydrolase 1) hydrolases have been shown to oxidise purine dNTPs and prevent their incorporation into DNA (7). Previous studies have also revealed that the levels and catalytic activity of MTH1 are increased in multiple cancer cell lines (8) and certain surgical specimens, including lung cancer (9), brain tumours $(10,11)$, renal (12), breast (13), colorectal (14) and oesophageal cancer (15). MTH1 overexpression inhibits reactive oxygen species-induced DNA damage and premature senescence (16). Based on these findings, MTH1 has been suggested as a potential drug candidate for cancer treatment. Studies $(8,17,18)$ revealed that MTH1 prevents the incorporation of oxidised dNTPs, such as 8-oxo-dG, into DNA and inhibits cell death. Although MTH1 is not essential in normal cells (8), it is required by cancer cells for survival, independent of their tissue origin $(8,18)$.

By contrast, some researchers have argued that certain MTH1 inhibitors do not suppress proliferation and induce apoptosis in certain human cancer cell lines $(19,20)$. The underlying reason is presumed to be off-target interaction of the MTH1 inhibitors with tubulin instead of MTH1 (21). To address this controversy, studies (18,22-24) have discovered a novel compound, TH1579. Compared with previously characterised MTH1 inhibitors, TH1579 showed higher potency (sub-nanomolar concentration) and more selective MTH1 inhibition, with good oral bioavailability. In recent studies $(25,26)$, TH1579 also showed excellent pharmacokinetic and antitumour effects in chemotherapy-resistant patient-derived malignant melanoma and human melanoma 
mouse xenograft models $(25,26)$. TH1579 prevents the accumulation of 8-oxo-dG and induces DNA damage and cell apoptosis without off-target interaction with tubulin (26). Additionally, recent evidence suggests that TH1579 inhibits MTH1 activity in glioblastoma and glioblastoma stem cells in vitro and in vivo (23), thus indicating that MTH1 may act as a potential anticancer target.

Although recent studies have demonstrated that MTH1 inhibitors are effective against gastric (27), liver (24) and bladder (28) cancers, the antitumour efficacy of MTH1 inhibitors against CRPC is not known. Moreover, some studies $(8,18)$ have discussed the probable cytotoxic effects of MTH1 inhibitors on human prostate cancers, including CRPC. The aim of the present study was to determine the antitumour efficacy of TH1579 against CRPC, and to investigate the underlying molecular mechanism of MTH1 inhibitors. Furthermore, the potential clinical use of MTH1 inhibitors against CRPC was investigated.

\section{Materials and methods}

Cell culture. Human prostate cancer cell lines (PC-3, DU-145 and C4-2) (all Procell Life Science \& Techology Co., Ltd.) were cultured in RPMI-1640 medium (Thermo Fisher Scientific, Inc.) supplemented with $10 \%$ foetal bovine serum (Thermo Fisher Scientific, Inc.) and penicillin-streptomycin $(90 \mathrm{U} / \mathrm{ml})$ at $37^{\circ} \mathrm{C}\left(5 \% \mathrm{CO}_{2}\right)$ in a humidified atmosphere. The cells were cultured in T-75 flasks and passaged by trypsinisation at $\sim 70 \%$ confluence.

TH1579 treatment and assessment of cell viability. Cells were seeded into 96 -well plates at a density of $6 \times 10^{4} / \mathrm{ml}$ ( $3 \times 10^{3}$ cells $/ 50 \mu \mathrm{l} /$ well). After $24 \mathrm{~h}$ of incubation in a humidified incubator $\left(37^{\circ} \mathrm{C}, 5 \% \mathrm{CO}_{2}\right)$, the cells were treated with TH1579 (HPLC purity, >98\%) purchased from ProbeChem ${ }^{\circledR}$, and incubated for an additional $72 \mathrm{~h}$ at $37^{\circ} \mathrm{C}$ and $5 \% \mathrm{CO}_{2}$. TH1579 was serially diluted to generate the following final concentrations: $0.0625,0.125,0.250,0.50$ and $1.0 \mu \mathrm{M}$. Each concentration of TH1579 was tested in triplicate (3 wells/TH1579 concentration), and dimethyl sulfoxide (DMSO) was used as the negative control. The reaction was terminated by the addition of $100 \mu \mathrm{l}$ resazurin dye solution ( $400 \mu \mathrm{l}$ in $20 \mathrm{ml}$; Sigma-Aldrich; Merck $\mathrm{KGaA}$ ) to each well, followed by further incubation for 2-3 h. Cell viability was determined by measuring the absorbance using the Hidex Sense microplate reader (Hidex Oy). In viable cells, the amount of oxidised resazurin (blue colour) is low, and that of reduced resazurin is high (pink-red colour). Therefore, viable cells fluoresce pinkish-red after a 2 -h incubation, whereas dead cells fluoresce blue.

Androgen receptor $(A R)$ silencing. For this experiment, $1 \times 10^{5}$ C4-2 cells (cat. no. GOY0197) which were previously inoculated with AR-targeted doxycycline-inducible short hairpin (sh)RNA (synthesized by Goybio), were seeded into each well of a 6-well plate and allowed to attach for $24 \mathrm{~h}$. Doxycycline $(1 \mu \mathrm{g} / \mathrm{ml})$ was added to each well and the cells were incubated for a further $72 \mathrm{~h}$ prior to experimentation. The synthesis of the shRNA construct, comprising AR-specific shRNA inserted in a doxycycline-inducible FH1tUTG lentiviral vector, has been previously described (8).
Western blot analysis

Preparation of cell lysates for protein extraction. PC-3 or

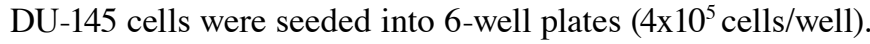
After 12-20 h of incubation, the cells were treated with DMSO, TH1579 $(0.5$ and $1 \mu \mathrm{M})$ or etoposide $(1 \mu \mathrm{M})$, and then incubated for $24 \mathrm{~h}$. The cells were then harvested on ice, washed once with cold PBS, trypsinised and centrifuged at $450 \mathrm{x} \mathrm{g}$ for $5 \mathrm{~min}$ at $25^{\circ} \mathrm{C}$. After two more washes and centrifugation cycles, 50-100 $\mu 1$ lysis buffer solution [1 ml lysis buffer solution $=890 \mu \mathrm{l}$ Lysis buffer, $100 \mu \mathrm{l}$ protease inhibitor (10X; both Roche Diagnostics) and $10 \mu \mathrm{l}$ of phosphatase inhibitor (100X; Thermo Fisher Scientific, Inc.)] was added to each cell pellet, followed by incubation on ice for $30 \mathrm{~min}$. Whole-cell lysates were sonicated for $1 \mathrm{~min}$ and centrifuged at 12,000 $\mathrm{x} \mathrm{g}$ and $4^{\circ} \mathrm{C}$ for $30 \mathrm{~min}$ to solubilise all proteins.

Determination of protein concentration. The supernatant from the whole-cell lysates were transferred to new tubes, and the protein concentration of each sample was determined using a Pierce ${ }^{\mathrm{TM}}$ BCA protein assay kit (Thermo Fisher Scientific, Inc.).

Gel electrophoresis and western blotting. To load $20 \mu \mathrm{g}$ protein per well, each sample was mixed with Laemmli SDS-PAGE sample buffer (Bio-Rad Laboratories, Inc.) at a 3:1 ratio. The samples were heated at $95^{\circ} \mathrm{C}$ for $5 \mathrm{~min}$, loaded onto 12-well Mini-PROTEAN TGX precast gels (Bio-Rad Laboratories, Inc.) and electrophoresed at $120 \mathrm{~V}$ for $\sim 1.5 \mathrm{~h}$. The samples were subsequently transferred onto a polyvinylidene difluoride membrane (cut into three strips for protein with different molecular weights: Low, medium, and high), which was then incubated with Odyssey blocking buffer (LI-COR Biosciences) for $30 \mathrm{~min}$ at $25^{\circ} \mathrm{C}$. After blocking, the membrane was incubated at $4^{\circ} \mathrm{C}$ overnight with primary antibodies in blocking buffer. The following antibodies were used: Mouse polyclonal anti-H2A.X (1:1,000; cat. no. 05636; EMD Millipore), rabbit monoclonal anti-histone $\mathrm{H} 3$ (1:1,000; cat. no. ab1791; Abcam), rabbit polyclonal anti-cleaved poly (ADP-ribose) polymerase (cPARP; 1:1,000; cat. no. 9541; Cell Signaling Technology, Inc), rabbit monoclonal anti-p-p53 (S15; 1:1,000; cat. no. 9284; Cell Signaling Technology, Inc.) and mouse monoclonal anti- $\beta$ actin (1:10,000; cat. no. ab6276; Abcam). After overnight incubation, the membrane was washed three times with TBS-Tween 20 (1:20 TBST; $10 \mathrm{~min} /$ wash) and incubated with IRDye-conjugated donkey anti-rabbit and donkey anti-mouse fluorescence secondary antibodies (1:5,000; cat. nos. 925-68073 and 926-32212; LI-COR Biosciences) in TBST at $25^{\circ} \mathrm{C}$ for $30 \mathrm{~min}$ in the dark. The membrane was subsequently washed three times with TBST (10 min/wash), and the protein bands were visualised using the LI-COR Odyssey imaging system (LI-COR Biosciences).

Flow cytometric analysis. PC-3 or DU-145 cells $\left(1 \times 10^{6} / \mathrm{ml}\right)$ were seeded into $25-\mathrm{cm}^{2}$ flasks at $25^{\circ} \mathrm{C}$, treated with TH1579 compounds, and harvested after $72 \mathrm{~h}$. The cells were washed twice with PBS, resuspended in $1 \mathrm{X}$ binding buffer and centrifuged at $450 \mathrm{x} g$ after mixing. The pellets were resuspended in a solution of FITC-Annexin V (Thermo Fisher Scientific; cat. no. A23204 and propidium iodide (PI; BD Biosciences; $900 \mu \mathrm{l}$ $1 \mathrm{X}$ binding buffer $+45 \mu \mathrm{l}$ FITC-Annexin $\mathrm{V}+45 \mu \mathrm{l}$ of PI for 
8 samples; $110 \mu \mathrm{l} / \mathrm{sample})$. After gentle vortexing, the solution was incubated at $25^{\circ} \mathrm{C}$ for $15 \mathrm{~min}$ in the dark. Subsequently, $400 \mu 11 \mathrm{X}$ binding buffer was added to each sample, and the sample mixture was transferred to new tubes within $15 \mathrm{~min}$ for flow cytometric analysis using the FACSCalibur Instrument (Becton, Dickinson and Company). The data were analysed using BD FACS Diva and CellQuest Pro software (cat. no. 643274; cat.no. Rev. A; both from BD Biosciences).

Immunofluorescence analysis. DU-145 or PC-3 cells $\left(2.5 \times 10^{5}\right)$ were seeded onto glass coverslips in a 6 -well plate, and incubated for $24 \mathrm{~h}$ before treatment with DMSO, TH1579 $(0.5$ and $1 \mu \mathrm{M})$ or etoposide $(1 \mu \mathrm{M})$; the cells were then incubated for an additional $24 \mathrm{~h}$, washed twice with $1 \mathrm{X}$ PBS, and fixed in $1 \mathrm{ml} 4 \%$ paraformaldehyde in PBS $+0.1 \%$ Triton $\mathrm{X}$ (PBS-T) at room temperature for $20 \mathrm{~min}$. The fixed cells were rinsed twice with PBS for 10 min each, permeabilised with PBS $+0.5 \%$ Triton $\mathrm{X}$ for 15 min, blocked with 3\% BSA (Thermo Fisher Scientific, Inc.) in PBS-T for $1 \mathrm{~h}$, and incubated at $4^{\circ} \mathrm{C}$ overnight with primary antibodies diluted in $3 \%$ BSA in PBS. The following primary antibodies were used: Mouse anti- $\gamma \mathrm{H} 2 \mathrm{AX}^{\mathrm{Ser} 139}(1: 1,000$; cat. no. 05-636; EMD Millipore;) and rabbit anti-p53-binding protein 1 (53BP1; 1:1,000; cat. no. ab36823; Abcam). After overnight incubation, the cells were rinsed three times with PBS-T for $10 \mathrm{~min}$ and incubated with fluorophore-conjugated donkey anti-rabbit IgG AlexaFluor488 and donkey anti-mouse IgG AlexaFluor555 secondary antibodies (1:500 in blocking solution; cat. no. R37118 and A32773; both from Molecular Probes; Thermo Fisher Scientific, Inc.;) at room temperature for $1 \mathrm{~h}$ in the dark. DNA was counterstained with DAPI (1:1,000; ATTO-TEC GmbH) in 1X PBS. Coverslips were mounted onto glass slides with one drop of ProLong Gold Antifade Reagent (Invitrogen; Thermo Fisher Scientific, Inc.) and dried overnight.

Each slide was imaged using an LSM 780 confocal laser scanning microscope (Zeiss $\mathrm{GmbH}$ ) with a planachromat 63x/NA 1.4 oil immersion objective at excitation wavelengths of 543 and $633 \mathrm{~nm}$. A total of 10 random fields were imaged for each slide and, subsequently, the cells in each field were counted. The expression of the DNA damage marker $\gamma \mathrm{H} 2 \mathrm{AX}$ was determined by counting cells with 53BP1 foci (a cell with $\geq 9$ 53BP1 foci was considered to be positive) and $\gamma \mathrm{H} 2 \mathrm{AX}$ foci; 10 field images were acquired to calculate the mean for each treatment condition.

Determination of 8-oxo-dG levels. DU-145 or PC-3 cells $\left(2.5 \times 10^{5}\right)$ were seeded onto glass coverslips in a 6 -well plate, incubated for $24 \mathrm{~h}$ before treatment with DMSO or TH1579 (0.5 and $1 \mu \mathrm{M})$, and incubated for an additional $24 \mathrm{~h}$. For the positive control, $50 \mathrm{mM}$ potassium bromate was added to one well $1 \mathrm{~h}$ before harvesting the cells. The harvested cells were washed twice with 1X PBS and fixed in chilled methanol/acetone $(1: 1)$ for $30 \mathrm{~min}$ at $-20^{\circ} \mathrm{C}$. The fixed cells were rinsed twice with $1 \mathrm{X}$ PBS for $10 \mathrm{~min}$ each, followed by denaturation with 2.5 normal concentration $(\mathrm{N}) \mathrm{HCl}$ at room temperature for $45 \mathrm{~min}$. Thereafter, cells were rinsed thrice with 1X PBS on a shaker for 5 min each, and neutralised with $0.1 \mathrm{M} \mathrm{Na}_{2} \mathrm{BO}_{4} \mathrm{O}_{7}(\mathrm{pH} 8.8)$ for $10 \mathrm{~min}$. The cells were again rinsed thrice with $1 \mathrm{X}$ PBS on a shaker for $5 \mathrm{~min}$ each, and then permeabilised with $0.5 \%$ Triton X-100 in PBS for 15 min. After rinsing thrice with $1 \mathrm{X}$ PBS for $5 \mathrm{~min}$, the cells were blocked with $4 \% \mathrm{BSA}$ in PBS for $1 \mathrm{~h}$ and incubated at $4{ }^{\circ} \mathrm{C}$ overnight with mouse anti-8 hydroxyguanosine (1:200; cat. no. ab48508; Abcam) primary antibody.

After overnight incubation, the cells were rinsed thrice with PBS-T for $10 \mathrm{~min}$ and incubated with fluorophore-conjugated donkey anti-mouse IgG AlexaFluor488 secondary antibody (1:500 in blocking solution; cat. no. A32766; Thermo Fisher Scientific, Inc.) at room temperature for $1 \mathrm{~h}$ in the dark. DNA was counterstained with DAPI $(1: 1,000)$ prepared in $1 \mathrm{X}$ PBS. The coverslips were mounted onto the slides with one drop of ProLong Gold Antifade Reagent and dried overnight. The slides were then imaged as aforementioned (Immunofluorescence analysis section), and 8-oxo-dG levels were quantified using an in-house software based on ImageJ from National Institutes of Health (DAPI was used as a marker of nuclear DNA).

Colony formation assay. For the colony formation assay, 500 cells in $10 \mathrm{ml}$ medium were seeded into a $10-\mathrm{cm}^{2}$ dish. The cells were treated with different concentrations of inhibitors $(10 \mu \mathrm{l} / \mathrm{dish})$ after incubation at $37^{\circ} \mathrm{C}$ for $5 \mathrm{~h}$; the culture medium was changed after every $72 \mathrm{~h}$. On day 10 , the colonies were fixed and stained with methylene blue $(4 \mathrm{~g} / \mathrm{l})$ in methanol and visualised manually for $30 \mathrm{~min}$ at $25^{\circ} \mathrm{C}$. A group of 30-50 cells was consider to be a colony and counted using a colony counter (aCOLade; Synbiosis; Synoptics Ltd.). Surviving fractions were calculated by comparison with DMSO-treated control cells.

Statistical analysis. Multiple comparisons between groups were performed with Tukey's test using GraphPad Prism 6 (GraphPad Software, Inc.). All the experiments were repeated for three times. Data are presented as the mean \pm SEM, and $\mathrm{P}<0.05$ was considered to indicate a statistically significant difference.

\section{Results}

TH1579 inhibits prostate cancer cell proliferation in a dose-dependent manner. The efficacy of the MTH1 inhibitor, TH1579, was determined using PC-3, DU-145 and C4-2 prostate cancer cell lines. In the present study, TH1579 was found to effectively kill both hormone-dependent and CRPC cells (Fig. 1A-C). The viabilities of PC-3, DU-145 and C4-2 (AR +/-) cells treated with $0.25,0.5$ and $1 \mu \mathrm{M}$ TH1579 were lower than those of cells in the DMSO control group $(\mathrm{P}<0.05)$. The viabilities of PC-3 and DU-145 cells treated with $1 \mu \mathrm{M}$ TH1579 were 28.6 and $24.1 \%$, respectively. The viabilities of C4-2 cells with and without AR treated with $1 \mu \mathrm{M}$ TH1579 were 10.6 and $19.0 \%$, respectively. Moreover, the viability of the C4-2 cells was not notably different between 1 and $0.5 \mu \mathrm{M}$ TH1579 treatment.

A colony formation assay was performed to determine the proliferation capacity of cells treated with TH1579 (Fig. 1C and D). The number of colonies from both prostate cancer cells treated with all concentrations of TH1579 was significantly lower $(\mathrm{P}<0.05)$ than that of the DMSO-treated control cells. However, the number of DU-145 cell colonies 


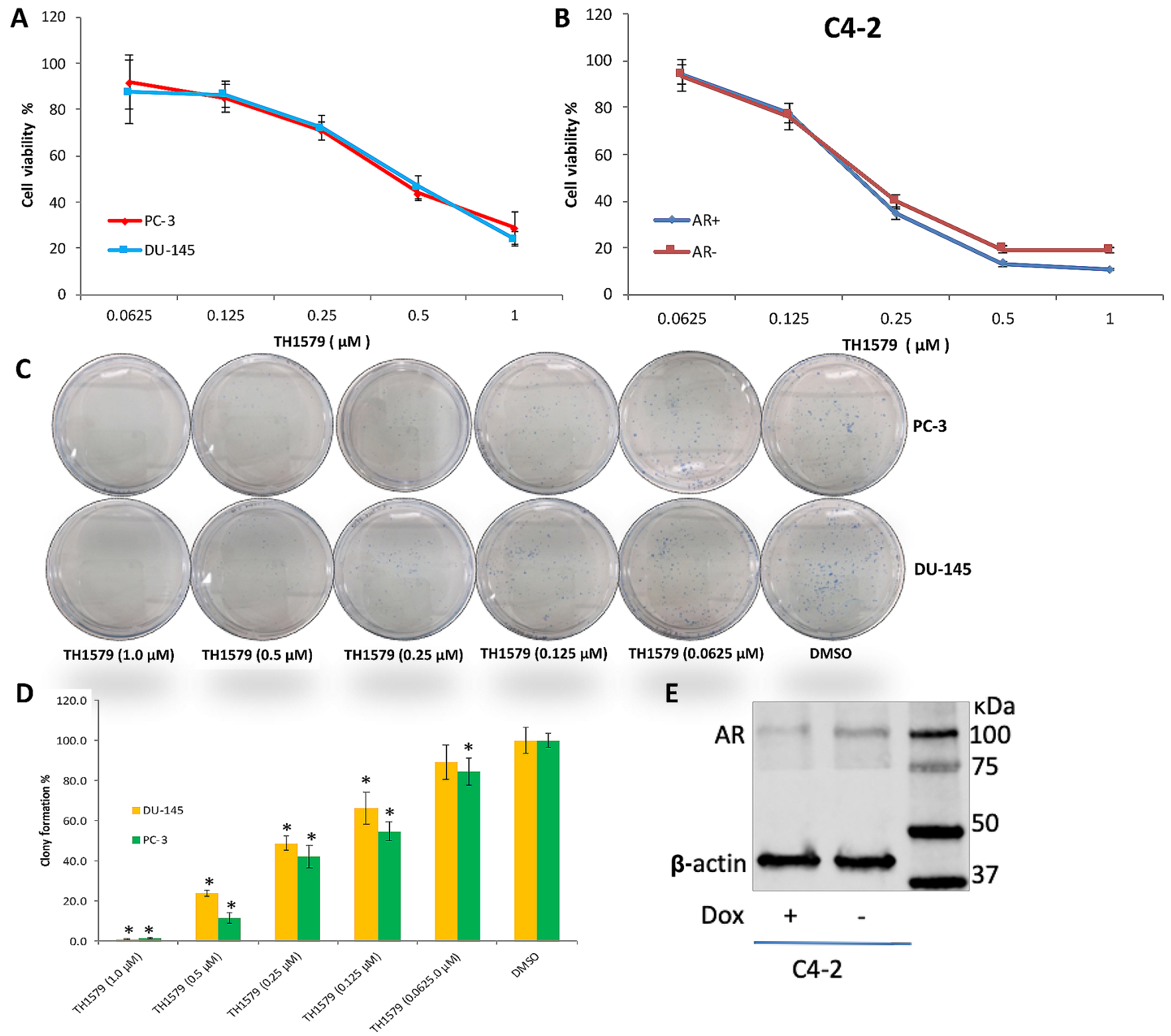

Figure 1. TH1579 inhibits the proliferation of prostate cancer cells in a dosage-dependent manner. Cellular viability assays were performed to show the percentage of (A) PC-3, DU-145 and (B) C4-2 (AR+/-), cells treated with a series concentration of TH1579 for $72 \mathrm{~h}$ relative to cells in the DMSO control group. Data are presented as the mean \pm SEM of $>3$ independent experiments. (C) Representative images of PC-3 and DU-145 cell colony formation 10 days after treatment with TH1579. (D) Quantification of clonogenic survival of DU-145 and PC-3 cells 10 days after treatment with TH1579. Values represent the percentage of colonies relative to DMSO-treated controls displayed as the mean \pm SEM of three independent experiments. ${ }^{*} \mathrm{P}<0.01$, each experiment group [including TH1579 $(1.0 \mu \mathrm{M})$, TH1579 $(0.5 \mu \mathrm{M})$, TH1579 $(0.25 \mu \mathrm{M})$, TH1579 $(0.125 \mu \mathrm{M})$, TH1579 $(0.0625 \mu \mathrm{M})$ ] vs. DMSO group, Tukey's test. (E) Western blot confirmation that C4-2 cell AR expression was suppressed after incubation with Dox (1 $\mu \mathrm{g} / \mathrm{ml})$ for $72 \mathrm{~h}$. AR, androgen receptor; Dox, doxycycline.

treated with $0.0625 \mu \mathrm{M}$ TH1579 was comparable to that of DMSO-treated cells (Fig. 1D). Therefore, the results indicated that TH1579 inhibited CRPC cell proliferation in a dose-dependent manner.

Western blotting was then performed to determine whether incubation of C4-2 cells with doxycycline for 3 days inhibits AR activity. The results suggested that the expression of AR in C4-2 cells was significantly inhibited by doxycycline (Fig. 1E).

TH1579 induces apoptosis in CRPC cells. To further understand the underlying mechanism of the antitumour activity of TH1579 on CRPC cells, flow cytometry and western blotting were performed. Flow cytometric analysis showed that the rate of apoptosis in PC-3 and DU-145 cells treated with TH1579 for $72 \mathrm{~h}$ was significantly higher than that in DMSO-treated control cells (only late apoptosis were assessed in the experiment; Fig. 2A and B). Western blotting revealed that the expression of apoptotic protein markers such as cPARP and $\gamma \mathrm{H} 2 \mathrm{~A} . \mathrm{X}$ was upregulated in these cells (Fig. 2C). Moreover, the expression of p53 (S15) was downregulated in PC-3 cells, owing to $p 53$ deletion (29).

$M T H 1$ inhibition promotes the incorporation of 8-oxo-dG into CRPC cells. An immunofluorescence assay was performed to determine the extent of 8-oxo-dG incorporation into the DNA of CRPC cells (Fig. 3A and B). As shown in Fig. 3C and $\mathrm{D}$, the level of 8-oxo-dG in PC-3 or DU-145 cells treated with TH1579 for $72 \mathrm{~h}$ was significantly higher than that in the 
A

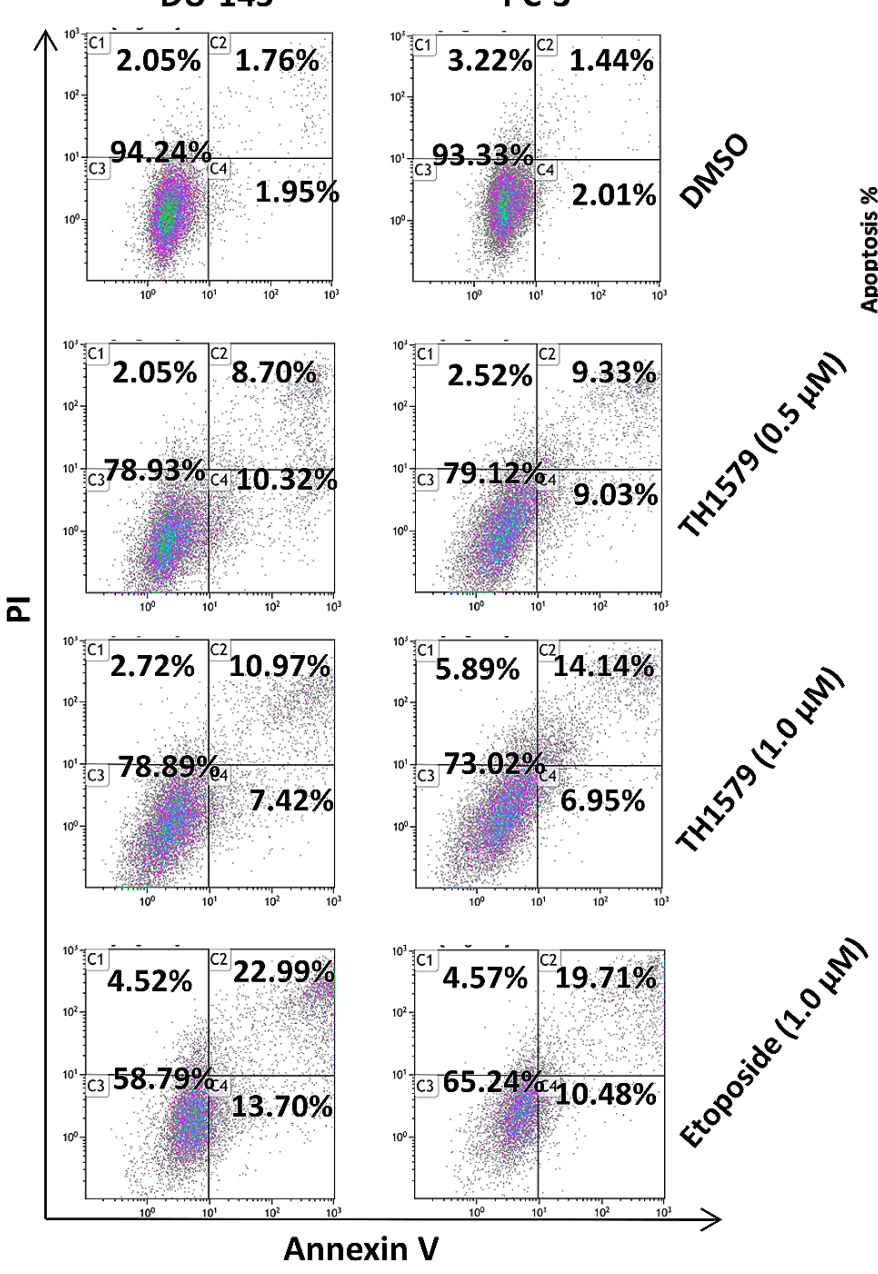

B
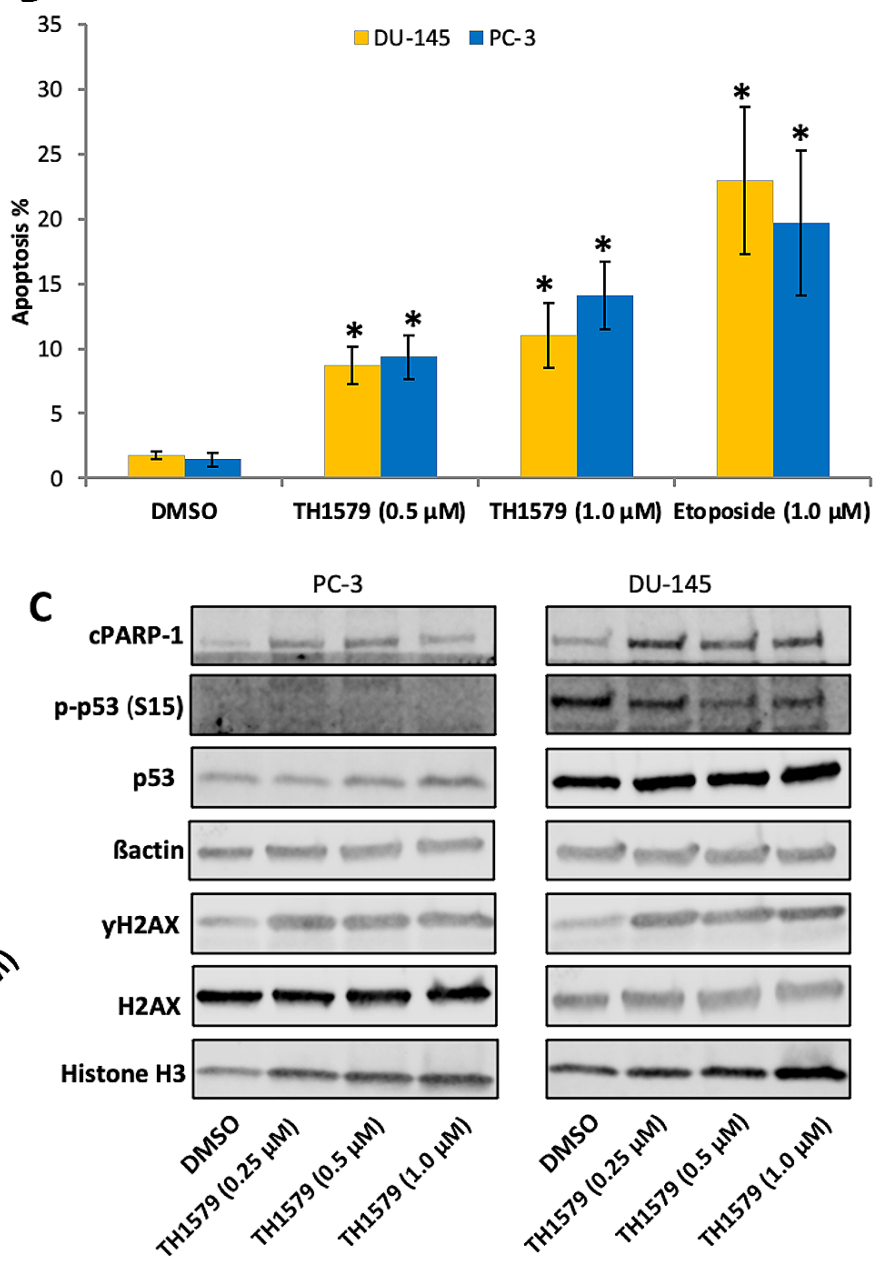

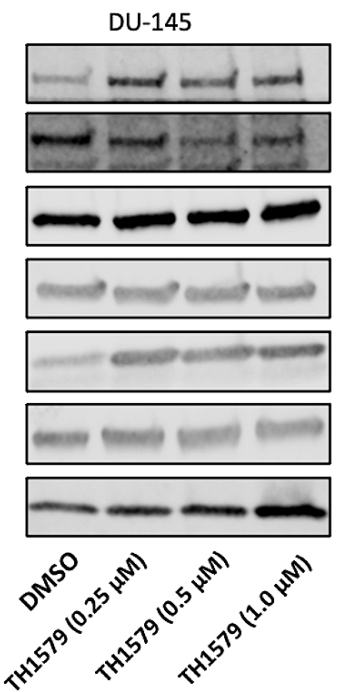

Figure 2. TH1579 induces apoptosis in castration-resistant prostate cancer. (A) Representative images of flow cytometric analysis highlighting apoptosis in DU-145 and PC-3 cells treated with TH1579 for $72 \mathrm{~h}$. (B) Flow cytometric quantification of apoptosis in PC-3 or DU-145 cells following PI and Annexin V staining. Values represent the mean \pm SEM from three independent experiments. " $\mathrm{P}<0.01$, each experiment group [including TH1579 (1.0 $\mu \mathrm{M})$, TH1579 $(0.5 \mu \mathrm{M})$ or Etoposide group vs. DMSO group]; Tukey's test. (C) Representative western blot images of cPARP-1, p-p53 (S15) and $\gamma \mathrm{H} 2 \mathrm{~A} . \mathrm{X}$ expression levels from $>3$ independent experiments $24 \mathrm{~h}$ after incubation with TH1579. cPARP-1, cleaved poly (ADP-ribose) polymerase 1; PI, propidium iodide.

DMSO-treated control cells $(\mathrm{P}<0.05)$. These results indicated that TH1579 inhibits the enzymatic activity of MTH1.

TH1579 promotes DNA double-strand breakage in CRPC cells. The accumulation of 8-oxo-dG in DNA can increase DNA double-strand breaks (DSBs) (4). 53BP1 is an important regulator of the cellular response to DNA DSBs and promotes end-joining of distal DNA ends (7). Phosphorylation of histone $\mathrm{H} 2 \mathrm{AX}$ at a serine four residues from the carboxyl terminus (to form $\gamma \mathrm{H} 2 \mathrm{AX}$ ) is considered to be a sensitive marker for DNA DSBs. $\gamma \mathrm{H} 2 \mathrm{AX}$ can also detect low levels of DNA damage $(8,18)$. To quantify DNA damage in PC-3 and DU-145 cells treated with TH1579 for $72 \mathrm{~h}$, these cells were stained with anti-53BP1 and anti- $\gamma \mathrm{H} 2 \mathrm{AX}$ antibodies. Immunofluorescence analysis revealed the accumulation of 53BP1 and $\gamma \mathrm{H} 2 \mathrm{AX}$ nuclear foci (Fig. 4A and B). Furthermore, confocal microscopy revealed that the number of 53BP1 and $\gamma \mathrm{H} 2 \mathrm{AX}$ nuclear foci in CRPC cells treated with $1 \mu \mathrm{M}$ TH1579 was significantly greater than that in DMSO-treated cells (Fig. 4C and D). These results provided substantial evidence that TH1579 inhibited MTH1 activity and induced DNA damage.

\section{Discussion}

Prostate cancer is a leading cause of mortality and morbidity among men. Although extensive attempts have been made to improve the understanding of the underlying mechanism of CRPC and its treatment efficiency (1-3,30-33), the clinical treatment of CRPC remains a challenge. The high heterogeneity of prostate cancer makes clinical stratification and selection of appropriate treatment strategies difficult $(1,2)$. Therefore, effective therapeutic strategies for CRPC are required to improve the overall survival of patients. To the best of our knowledge, the present study is the first to determine the antitumour effects and underlying molecular mechanisms of the MTH1 inhibitor, TH1579, in human prostate cancer cells.

In the present study, cell viability and colony formation assays were performed to demonstrate that TH1579 exhibits antitumour activity against PC-3 and DU-145 cells in a dose-dependent manner. Previous studies have shown that TH1579 exerts antitumour activity against osteosarcoma, colorectal cancer, drug-resistant bladder cancer, glioblastoma 

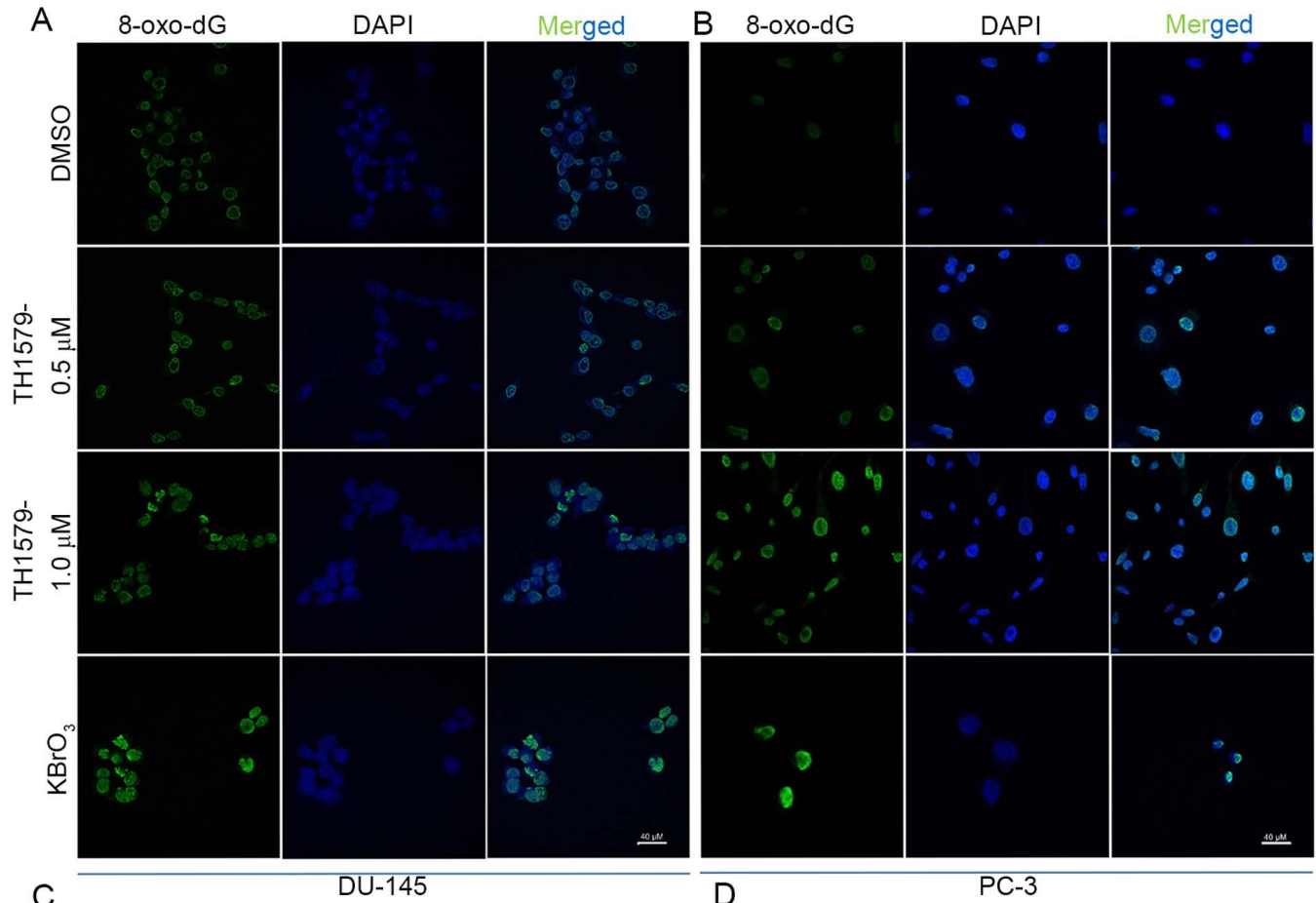

C

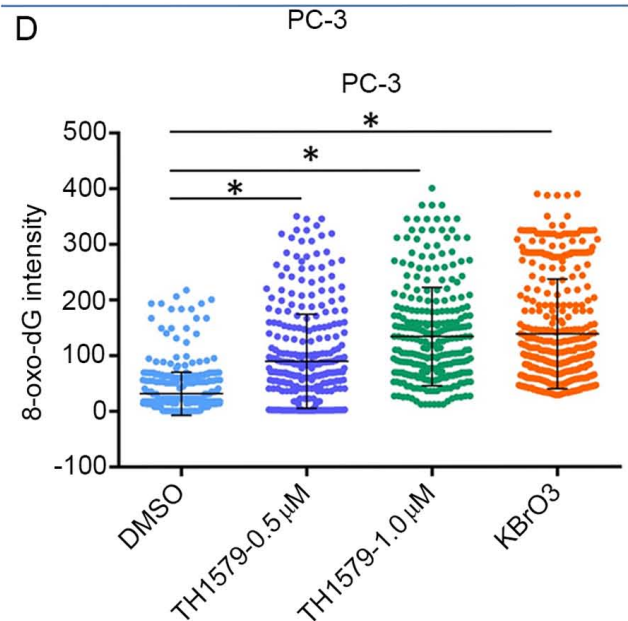

Figure 3. TH1579 promotes 8-oxo-dG incorporation into castration-resistant prostate cancer cells. Representative immunofluorescence images of 8-oxo-dG accumulation in (A) DU-145 and (B) PC-3 cells after incubation with TH1579 for $72 \mathrm{~h}$. Quantification of 8-oxo-dG intensity in (C) DU-145 and (D) PC-3 cells after $72 \mathrm{~h}$ treatment with $\mathrm{TH} 1579$ or $\mathrm{KBrO}_{3}$. Data are shown as the mean \pm SEM from three independent experiments; $\geq 200$ cells/sample. ${ }^{*} \mathrm{P}<0.01$, Tukey's test. $\mathrm{KBrO} 3$, potassium bromate.

and hepatic cancer cells both in vitro and in vivo $(18,23,24)$. In these studies, TH1579 increased 8-oxo-dG levels, as well as the number of $\gamma \mathrm{H} 2 \mathrm{AX}$ and 53BP1 nuclear foci (DNA damage markers), and decreased the size of xenograft tumours in mice in vivo. The present study presented evidence supporting the use of TH1579 as a therapeutic target for CRPC. Immunofluorescence assay results showed that TH1579 treatment increased 8-oxo-dG levels and promoted 53BP1 and $\gamma \mathrm{H} 2 \mathrm{~A}$.X foci formation in prostate cancer cells. Moreover, flow cytometry assays indicated that TH1579 treatment increased the rate of apoptosis and decreased the viability of DU-145 and PC-3 cells. These findings are in agreement with those of previous studies $(18,23,24)$. Considering these points, this MTH1 inhibitor may be beneficial as a novel clinical treatment against CRPC. However, further in vivo studies are required to confirm the clinical efficacy of the compound without unacceptable off-target toxicity.
Although the antitumour activity of TH1579 on cancer cells is well known, the underlying mechanism is not clear (18). A previous study suggested that the MTH1 inhibitors TH588 or TH287 exhibit antitumour activity by targeting tubulin, but not MTH1 (8). However, Warpman Berglund et al (18) demonstrated that these MTH1 inhibitors are not fully effective due to their inability to incorporate 8-oxo-dG into the DNA. In the present study, accumulation of 8 -oxo-dG in cellular DNA was observed after treatment with TH1579 for $72 \mathrm{~h}$. Simultaneously, increased 53BP1 and $\gamma \mathrm{H} 2 \mathrm{AX}$ foci formation in PC-3 and DU-145 cells was also observed. These findings suggested that TH1579 can induce CRPC cell apoptosis and suppress cancer cell proliferation by targeting MTH1.

TH1579 killed both AR-expressing and AR-deficient C4-2 cells, indicating that the antitumour activity of TH1579 was independent of AR signalling. However, a previous study (34) proposed that AR signalling is essential for the 
A
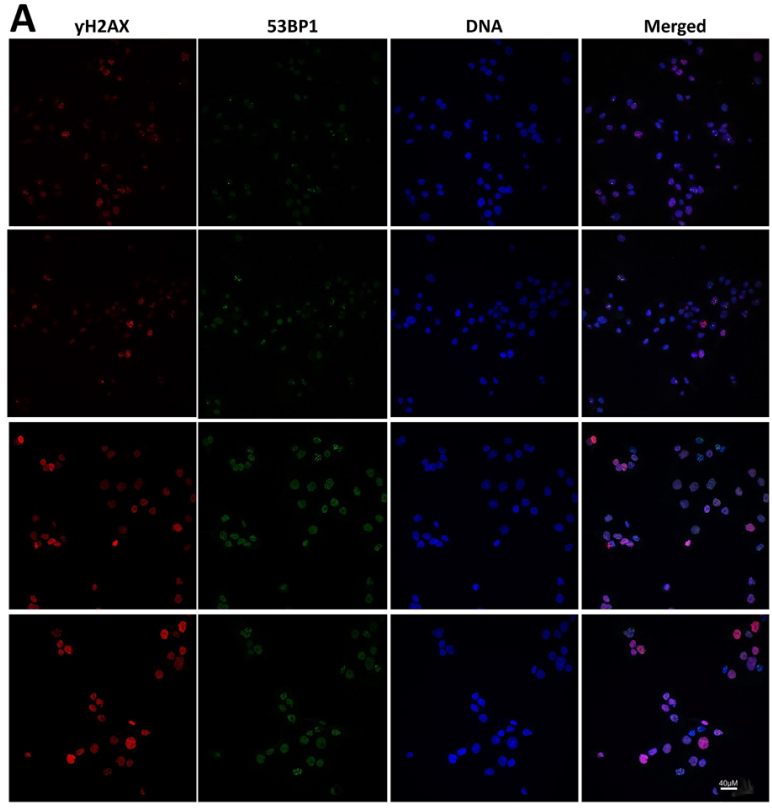

C

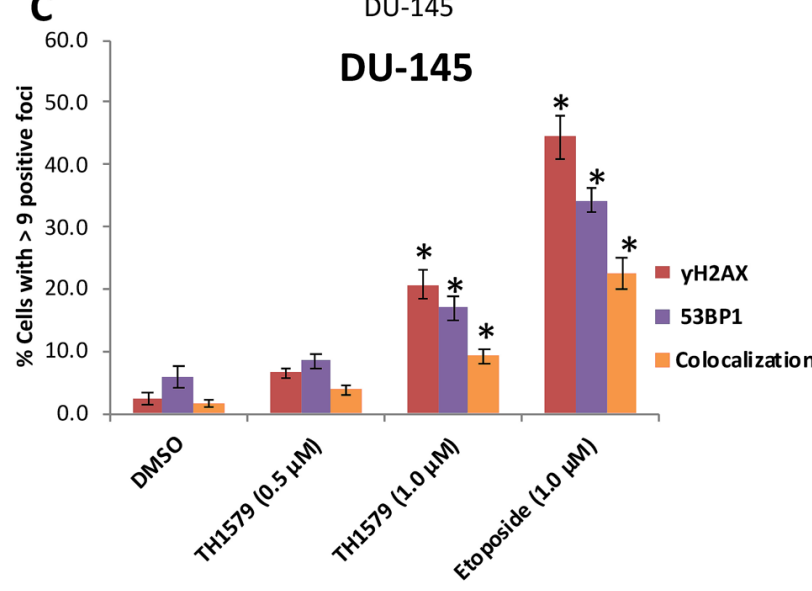

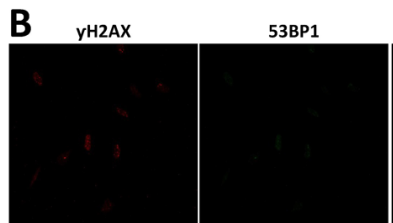
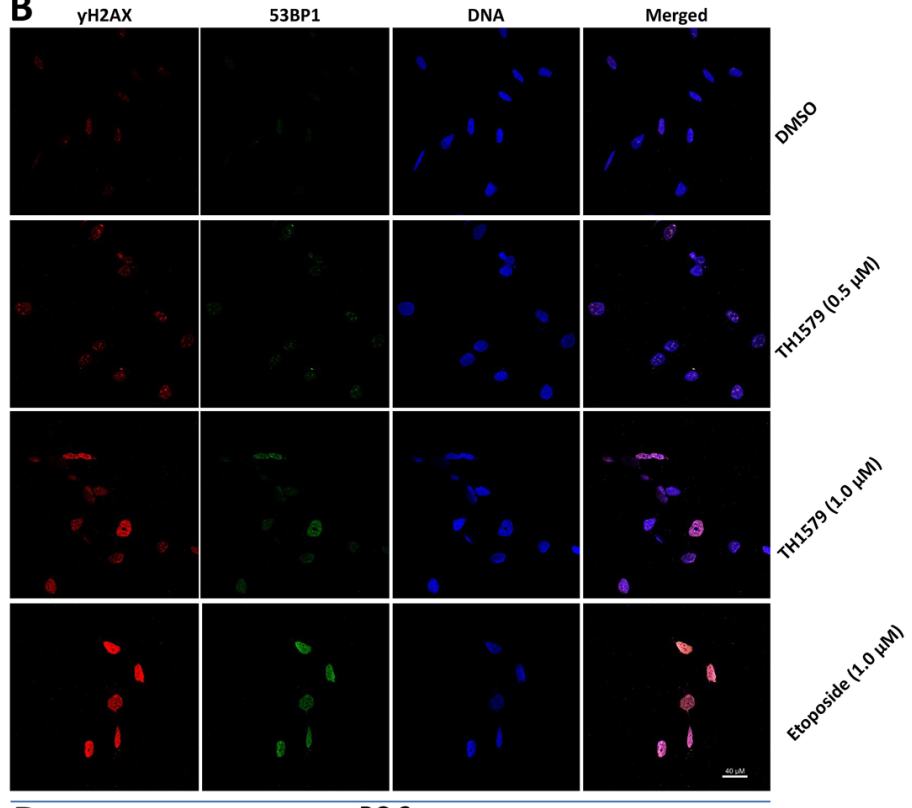

D

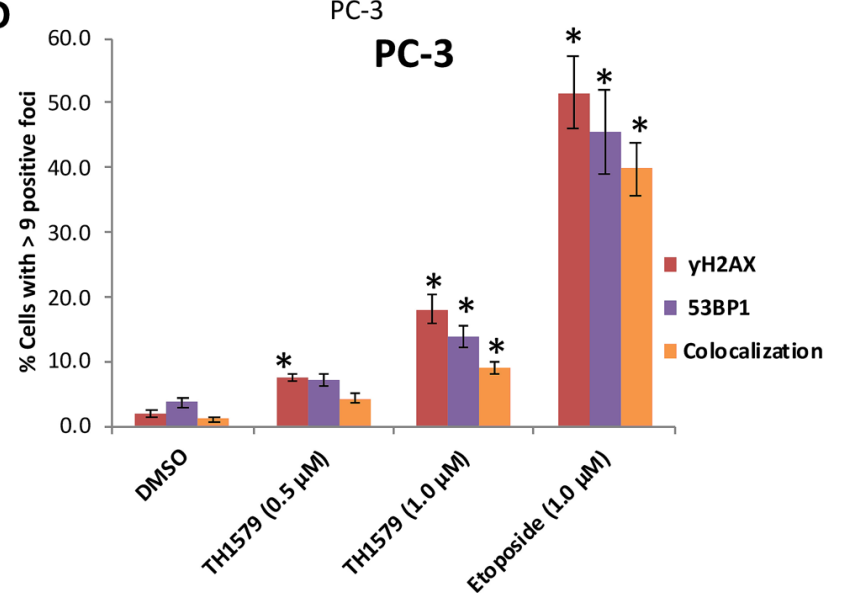

Figure 4. TH1579 promotes DNA double-strand breakage and DNA damage in castration-resistant prostate cancer cells, indicated by 53BP1 and $\gamma \mathrm{H} 2 \mathrm{AX}$ foci. Representative immunofluorescence staining images of $\gamma \mathrm{H} 2 \mathrm{AX}$ foci (red) and 53BP1 foci (green) accumulation in DNA and colocalisation in (A) DU-145 and (B) PC-3 cells 3 days after treatment with TH1579. DNA was counterstained with DAPI. Colocalisation of the red $\gamma \mathrm{H} 2 \mathrm{AX}$ and green 53BP1 foci is indicated by yellow foci in the merged fields. Quantification of (C) DU-145 and (D) PC-3 cells with $\gamma \mathrm{H} 2 \mathrm{AX}$ and/or 53BP1 positive foci after 72 h treatment with TH1579 or etoposide. Data are shown as Mean \pm SE from three independent experiments; $\geq 200$ cells/sample. * $<<0.01$, each experiment group including TH1579 $(1.0 \mu \mathrm{M})$, TH1579 $(0.5 \mu \mathrm{M})$ or Etoposide group vs. DMSO group; Tukey's test. 53BP1, p53-binding protein 1.

regulation of DNA repair. Moreover, the present study indicated that DU-145 cells are more sensitive to TH1579 treatment than PC-3 cells. This result suggested that the antitumour activity of TH1579 is associated with p53 status, as PC-3 cells, but not DU-145 cells, carry a p53 deletion mutation. Although this result is in agreement with that of a previous study (8), it may require further investigation.

Although MTH1 is required for the survival of cancer cells, the downregulation of MTH1 mRNA expression does not inhibit the proliferation of all cell lines (8). While certain studies have suggested genetic or phenotypic resistance mechanisms for this phenomenon, others have hypothesized that MTH1 is not required for the proliferation of all cancer cell types $(8,18)$. Moreover, chemical inhibition of MTH1 with inhibitors such as TH1579 or TH588 is more efficient at suppressing tumour cell proliferation than siRNA-mediated silencing of MTH1 (18). A compensatory mechanism through the gradual exhaustion of MTH1 has been suggested to be responsible for this phenomenon (18). Therefore, it can be inferred that chemical inhibition or gene silencing may not always be therapeutically effective for tumour treatment.

Another drawback of using TH1579 is that the inhibition of MTH1 function may increase spontaneous mutagenesis and carcinogenesis (35). However, these data were obtained using a mouse model; the time required to cause spontaneous mutagenesis and carcinogenesis in humans may be far longer. Given that most patients with advanced prostate cancer are over 70 years of age, this should not be a primary concern for their treatment compared with attempting to prolong their lifespan.

In conclusion, the results of the present study suggested that TH1579 may be a potential potent chemotherapeutic agent for treating patients with hormone-naïve prostate cancer or CRPC. Further studies are required to validate the antitumour activity and underlying molecular mechanisms of MTH1 inhibitors in human CRPC cells. 


\section{Acknowledgements}

Not applicable.

\section{Funding}

The present study was funded by the Key Projects of Provincial Educational Department, Anhui Province, China Mainland (grant no. KJ2019A0373), and Bengbu Medical College, Anhui Province, China mainland (grant no. BYKC201912).

\section{Availability of data and materials}

The datasets used and/or analyzed during the current study are available from the corresponding author on reasonable request.

\section{Authors' contributions}

MH analyzed and interpreted the experiment data. JN, LM, YY and YW performed the western blotting, cellular viability, immunofluorescence and flow cytometry assay experiments. MH wrote the manuscript. All authors read and approved the final manuscript.

\section{Ethics approval and consent to participate}

Not applicable.

\section{Patient consent for publication}

Not applicable.

\section{Competing interests}

The authors declare that they have no competing interests.

\section{References}

1. Wong MC, Goggins WB, Wang HH, Fung FD, Leung C, Wong SY, Ng CF and Sung JJ: Global incidence and mortality for prostate cancer: Analysis of temporal patterns and trends in 36 countries. Eur Urol 7: 862-874, 2016

2. Crawford ED, Higano CS, Shore ND, Hussain M and Petrylak DP: Treating patients with metastatic castration resistant prostate cancer: A comprehensive review of available therapies. J Urol 194: 1537-1547, 2015.

3. van Dodewaard-de Jong JM, Verheul HMW, Bloemendal HJ de Klerk JMH, Carducci MA and van den Eertwegh AJM: New Treatment options for patients with metastatic prostate cancer: What is the optimal sequence? Clin Genitourin Cancer 13 271-279, 2015

4. Jackson SP and Bartek J: The DNA-damage response in human biology and disease. Nature 461: 1071-1078, 2009.

5. Hah SS, Mundt JM, Kim HM, Sumbad RA, Turteltaub KW and Henderson PT: Measurement of 7,8-dihydro-8-oxo-2'-deoxyguanosine metabolism in MCF-7 cells at low concentrations using accelerator mass spectrometry. Proc Natl Acad Sci USA 104 11203-11208, 2007.

6. Zhang Y, Du Y, Le W, Wang K, Kieffer N and Zhang J: Redox control of the survival of healthy and diseased cells. Antioxid Redox Signal 15: 2867-2908, 2011

7. Nakabeppu Y: Cellular levels of 8-oxoguanine in either DNA or the nucleotide pool play pivotal roles in carcinogenesis and survival of cancer cells. Int J Mol Sci 15: 12543-12557, 2014.

8. Gad H, Koolmeister T, Jemth AS, Eshtad S, Jacques SA, Ström CE, Svensson LM, Schultz N, Lundback T, Einarsdottir BO, et al: MTH1 inhibition eradicates cancer by preventing sanitation of the dNTP pool. Nature 508: 215-221, 2014.
9. Kennedy CH, Pass HI and Mitchell JB: Overexpression of human mutT homologue (hMTH1) protein as a marker of persistent oxidative stress in primary non-small cell lung tumors. Free Radic Biol Med 34: 1447-1457, 2003.

10. Iida T, Furuta A, Kawashima M, Nishida J, Nakabeppu Y and Iwaki T: Accumulation of 8-oxo-2'-deoxyguanosine and increased expression of hMTH1 protein in brain tumors. Neuro Oncol 3: 73-81, 2001.

11. Tu Y, Wang Z, Wang X, Yang H, Zhang P, Johnson M, Liu N, Liu H, Jin W, Zhang Y, et al: Birth of MTH1 as a therapeutic target for glioblastoma: MTH1 is indispensable for glioma tumorigenesis. Am J Transl Res 8: 2803-2811, 2016.

12. Okamoto K, Toyokuni S, Kim WJ, Ogawa O, Kakehi Y, Arao S, Hiai $\mathrm{H}$ and Yoshida O: Overexpression of human mutT homologue gene messenger RNA in renal-cell carcinoma: Evidence of persistent oxidative stress in cancer. Int J Cancer 65: 437-441, 1996.

13. Zhang X, Song W, Zhou Y, Mao F, Lin Y, Guan J and Sun Q: Expression and function of MutT homolog 1 in distinct sub-types of breast cancer. Oncol Lett 13: 2161-2168, 2017.

14. Koketsu S, Watanabe T and Nagawa H: Expression of DNA repair protein: MYH, NTH1, and MTH1 in colorectal cancer. Hepatogastroenterology 51: 638-642, 2004.

15. Akiyama S, Saeki H, Nakashima Y, Iimori M, Kitao H, Oki E. Oda Y, Nakabeppu Y, Kakeji Y and Maehara Y: Prognostic impact of MutT homolog-1 expression on esophageal squamous cell carcinoma. Cancer Med 6: 258-266, 2017.

16. Rai P, Young JJ, Burton DG, Giribaldi MG, Onder TT and Weinberg RA: Enhanced elimination of oxidized guanine nucleotides inhibits oncogenic RAS-induced DNA damage and premature senescence. Oncogene 30: 1489-1496, 2011.

17. Huber KV, Salah E, Radic B, Gridling M, Elkins JM, Stukalov A Jemth AS, Gokturk C, Sanjiv K, Strömberg K, et al: Stereospecific targeting of MTH1 by (S)-crizotinib as an anticancer strategy. Nature 508: 222-227, 2014.

18. Warpman Berglund U, Sanjiv K, Gad H, Kalderén C, Koolmeister T, Pham T, Gokturk C, Jafari R, Maddalo G, Seashore-Ludlow B, et al: Validation and development of MTH1 inhibitors for treatment of cancer. Ann Oncol 27: 2275-2283, 2016.

19. Kettle JG, Alwan H, Bista M, Breed J, Davies NL, Eckersley K, Fillery S, Foote KM, Goodwin L, Jones DR, et al: Potent and selective inhibitors of MTH1 probe its role in cancer cell survival. J Med Chem 59: 2346-2361, 2016.

20. Petrocchi A, Leo E, Reyna NJ, Hamilton MM, Shi X, Parker CA, Mseeh F, Bardenhagen JP, Leonard P, Cross JB, et al: Identification of potent and selective MTH1 inhibitors. Bioorg Med Chem Lett 26: 1503-1507, 2016.

21. Kawamura T, Kawatani M, Muroi M, Kondoh Y, Futamura Y, Aono H, Tanaka M, Honda K and Osada H: Proteomic profiling of small-molecule inhibitors reveals dispensability of MTH1 for cancer cell survival. Sci Rep 6: 26521, 2016.

22. Scobie M, Helleday T, Koolmeister T, Jacques S, Desroses M and Jacques-cordonnier M: Pyrimidine-2,4-diamine derivatives for treatment of cancer, WO2014084778.

23. Pudelko L, Rouhi P, Sanjiv K, Gad H, Kalderén C, Höglund A, Squatrito M, Schuhmacher AJ, Edwards S, Hägerstrand D, et al: Glioblastoma and glioblastoma stem cells are dependent on functional MTH1. Oncotarget 8: 84671-84684, 2017.

24. Hua X, Sanjiv K, Gad H, Pham T, Gokturk C, Rasti A, Zhao Z, He K, Feng M, Zang Y, et al: Karonudib is a promising anticancer therapy in hepatocellular carcinoma. Ther Adv Med Oncol 11: $1758835919866960,2019$.

25. Das I, Gad H, Brautigam L, Pudelko L, Tuminen R, Helleday T, Hansson J, Brage S and Berglund U: 1180 Effects of MTH1 inhibitor TH1579 on cutaneous melanoma. J Invest Dermat 138: S200, 2018.

26. Einarsdottir BO, Karlsson J, Söderberg EMV, Lindberg MF, Funck-Brentano E, Jespersen H, Brynjolfsson SF, Olofsson Bagge R, Carstam L, Carstam L, et al: A patient-derived xenograft pre-clinical trial reveals treatment responses and a resistance mechanism to karonudib in metastatic melanoma. Cell Death Dis 9: 810, 2018.

27. Zhou W, Ma L, Yang J, Qiao H, Li L, Guo Q, Ma J, Zhao L, Wang J, Jiang G, et al: Potent and specific MTH1 inhibitors targeting gastric cancer. Cell Death Dis 10: 434, 2019.

28. Lee JW, Lee S, Ho JN, Youn JI, Byun SS and Lee E: Antitumor effects of MutT homolog 1 inhibitors in human bladder cancer cells. Biosci Biotechnol Biochem 83: 2265-2271, 2019. 
29. Carroll AG, Voeller HJ, Sugars L and Gelmann EP: p53 oncogene mutations in three human prostate cancer cell lines. Prostate 23: 123-134, 1993

30. Mamidi TKK, Wu J and Hicks C: Integrating germline and somatic variation information using genomic data for the discovery of biomarkers in prostate cancer. BMC Cancer 19: $229,2019$.

31. Asim M, Tarish F, Zecchini HI, Sanjiv K, Gelali E, Massie CE, Baridi A, Warren AY, Zhao W, Ogris C, et al: Synthetic lethality between androgen receptor signalling and the PARP pathway in prostate cancer. Nat Commun 8: 374, 2017.

32. Popovics P, Schally AV, Szalontay L, Block NL and Rick FG: Targeted cytotoxic analog of luteinizing hormone-releasing hormone (LHRH), AEZS-108 (AN-152), inhibits the growth of DU-145 human castration-resistant prostate cancer in vivo and in vitro through elevating p21 and ROS levels. Oncotarget 5: 4567-4578, 2014.
33. Lorente D, Mateo J, Perez-Lopez R, de Bono JS and Attard G: Sequencing of agents in castration-resistant prostate cancer. Lancet Oncol 16: e279-292, 2015.

34. Knudsen KE: The AR-DNA repair axis: Insights into prostate cancer aggressiveness. Can J Urol 26 (5 Suppl 2): S22-S23, 2019.

35. Nakabeppu Y, Ohta E and Abolhassani N: MTH1 as a nucleotide pool sanitizing enzyme: Friend or foe? Free Radic Biol Med 107: 151-158, 2017.

This work is licensed under a Creative Commons Attribution-NonCommercial-NoDerivatives 4.0 International (CC BY-NC-ND 4.0) License. 